\title{
THE CONCEPT OF LAWS IN SOCIAL SCIENCE: A CRITIQUE AND NOTES ON AN EXPANDED VIEW*
}

\author{
MALCOLM M. FEELEY \\ Yale University
}

\section{INTRODUCTION}

During the past decade there has been a resurgence of interest in the problem of law and social control. Indicative of this interest, a rekindling of an earlier tradition, is the founding of the Law and Society Association and its journal the Law \& Society Review, the growth of course offerings both in law schools and social science departments, and the emergence of a rapidly growing body of literature. Research interests in this area, often captured by such terms as impact, compliance, legal effectiveness, and law and social change, have diverged from the traditional preoccupation with the development and meaning of formal legal doctrine and from the more recent behavioral concerns with judicial decisionmaking, to address the broader questions of the effects of law on society at large. ${ }^{1}$ While varying in breadth, depth, and precise focus, most of this research treats law as an independent variable and its consequences as the dependent variables, the events caused by the law. In the language of systems theory, the formal legal rules are the "policy outputs" while changes-of whatever scope-are the "policy outcomes." Although these studies vary from one-shot case histories to projects involving multiple controls and multiple time series analyses, they all tend to conform to this general design.

Another distinguishing feature of this body of work is that it attempts to measure the effectiveness of laws. This problem is typically characterized as the examination of the "gap" between the ideal of the law and the actual practices flowing from it, and has led to searches for the characteristics that laws must possess and the social conditions that must be present if a law is to accomplish its stated goals. This concern is often accompanied

* An earlier version of this paper was presented at the 1974 annual meetings of the American Political Science Association.

1. A list of published works in this area is too long to include here. There are, however, a number of widely read collections which contain representative samples of some of the best work in this area. See Simon (1968), Friedman and Macaulay (1969), Schwartz and Skolnick (1970), Grossman and Grossman (1971), Becker and Feeley (1972), Krislov et al. (1972), Black and Mileski (1973), and Akers and Hawkins (1975). In addition see Wasby (1970). 
by other questions as well. Under what conditions can law bring about social change or attitude change? Under what circumstances will law be obeyed? How efficacious is the deterrent function of the law? How important is law in maintaining social control?

The common basis of this research goes beyond a shared methodological perspective. The most important shared feature of this research is a common understanding of the concept of law and of its functions. Although most scholars do not explicitly define the concept of law, most contemporary social scientists hold an Austinian concept, and would probably agree in large measure with the following definition by Hoebel (1954:28):

.. . for working purposes law may be defined in the terms: A social norm is legal if its neglect or infraction is regularly met, in threat or in fact, by the application of physical force by an individual or group possessing the socially recognized privilege of so acting.

That is, law is viewed as a command or order to do or refrain from doing some specified act(s), and is distinguished from other norms by the threat of physical coercion attached to the order. $^{2}$

In sum, despite many important differences, two main features characterize the approaches of most of the current social science research on law and society: 1) the basic research problem is regarded as the investigation of the "gap" between the legal ideal and actual practices, and 2) law is understood as a command supported by sanction. It is my contention that both these views are inadequate and misleading. The characterization of the research problem as the examination of the "gap" between the "ideal" and "real" is theoretically indefensible, and the characterization of law as command is much too narrow. The result is that little theoretically useful work is being pursued, and that generalizations about the functioning of law are based on too narrow a notion of law. In the following sections I shall examine both these assertions, propose some alternatives, and then move toward development of a more inclusive framework.

\section{SHORTCOMINGS OF CURRENT APPROACHES}

\section{A. Problems of Goal Identification}

A standard feature of the legal effectiveness approach is to posit the ideal or goal of a law as a benchmark and then measure

2. Compare this definition with Austin's discussion $(1955,14 \mathrm{ff})$. 
the extent to which it is or is not being met. Thus, for instance, it has been argued (e.g., by Wasby, 170: 247ff) that the Supreme Court's reapportionment decisions were relatively successful in securing their intended consequences while the school desegregation decisions were not. Implicit in such an approach is the assumption that it is possible to identify, operationalize, and measure the goals of the law. Goals may be drawn from the explicit language of the law or discerned as implicit in the law. Others may cast their nets more broadly, contrasting actual practices with a generalized ideal or set of standards regarded as implicit in the spirit of the law."

Interestingly, the specification of such goals-the law-intheory-is rarely regarded as problematic by the researchers who follow this approach. ${ }^{4}$ Typically legal goals tend to be viewed as self-evident or easily identified and are posited without much ado. Frequently they are not even restated by the researchers with much precision or explicitness." Thus the basis of comparison-the standard against which reality is measured-is rarely clearly identified and operationalized. ${ }^{6}$ This is a common feature of both narrowly drawn studies and more ambitious ones. One indication of their vagueness is that these posited ideals can often be countered with distinctly different views that others have derived from the same body of laws. ${ }^{7}$

3. The several studies (such as Yale Law Journal, 1967) of compliance with the Supreme Court's Miranda decision are apt examples of the first approach, while various studies (such as Crain, et al. [1969]) of reactions to the federal courts' rulings on school desegregation exemplify the second. Skolnick's (1966) and Blumberg's (1970) studies of criminal justice practices are examples of the third.

4. On this point, see Black (1972a:) and Abel (1973:). As the problem appears in the research on criminal justice see Freeley (1973).

5. Skolnick's (1966) study of the police, for example, regularly compares observed practices with an unarticulated ideal of due process and the standard of a policeman's role in a democratic society. Blumberg (1970) holds up a particular adversarial ideal which he assumes is required by the law and against which he contrasts the "divergences" of observed practices, but this ideal is not specified with any precision nor is it specifically and unambiguously derivable from provisions in the law. Even Sudnow (1965) in his discussion of public defenders and "normal crimes" seems to have an implicit private practitioner standard against which he contrasts the behavior of public defenders.

6. Standard procedures in evaluation research, on the other hand, call for relative comparisons of possible alternatives. The basis for comparison and evaluation is neither an ill-defined ideal nor an absolute goal, but rather is a set of other possible alternatives (Suchman, 1967). While this strategy for comparison seems desirable for impact studies, unfortunately it will probably not be followed since it is a clear acknowledgment that the research is applied research, not "theoretical social science."

7. See, for example, the various views on the constitutionality of preventive detention. Contrast Dershowitz (1973), with Mitchell (1969). On prohibition, see Gusfield (1963). 
An approach which characterizes a research problem in terms of the examination of the gap between the law-in-theory and the law-in-action is essentially a normative not a scientific endeavor. ${ }^{8}$ Ironically, the very feature that may make it appear to be "objective" is the very cause of its value biases. There are two dimensions to this problem.

First, the language of the law is frequently so vague that the specific behavior it "commands" is not unambiguous or clearly derivable from it. The nature of the judicial and legislative process tends to institutionalize this ambiguity. Appellate judges frequently make new laws by haltingly moving away from an unsatisfactory position rather than precisely stating a new goal, and legislators frequently can agree only by increasing the ambiguity of statutory language. The task of goal specification becomes even more complicated as one moves away from the examination of a narrow and relatively specific rule to a complex of interrelated court rulings, legislative actions, and administrative directives. Here the task of specifying precise goals frequently gives way to the elaboration of a more generalized set of expectations (i.e., the "spirit" of the laws) which cannot meaningfully be broken down into constituent elements whose effects can be independently measured.

There is a second and much more serious obstacle to this "effectiveness" approach. By focusing on a single goal or set of goals-the formally stated purpose-a serious distortion is introduced into the analysis. What is posited in the name of detached objectivity as "the" goals or purposes of the law can in fact be a substitution of the researcher's own-or someone else's-goals and values for those held either by the promulgators or the "recipients" of the law. For example, in studying the implementation of provisions of the Safe Streets Act of 1968 which mandate the development of statewide criminal justice plans, I met with responses varying from a belief that the provisions ultimately envision a single state criminal justice budget to a belief that they may be virtually ignored since the "real" purpose of the Act was purely symbolic. Thus by adopting as a standard or benchmark the literal (or implied) formal goals of the law, considerable ambiguity and unsuspected bias may creep into the analysis. Social scientists tend to be suspicious of formal declarations of the goals of formal organizations (Etzioni, 1960; Mohr, 1973). The law seems especially worthy of this same skepticism.

8. For a more detailed statement on this point see Black (1972a). 


\section{B. Is Law Generic?}

So far my criticism of the legal effectiveness approach has been methodological, focusing on the problems of identifying the goals of laws. Another problem that can appropriately be raised here is whether law is so distinctive a social phenomena that it can serve as a core concept in the development of general social theory. My answer is that it probably is not: law does not perform a unique social function, nor is it a singular form of social control. Hence it need not be singled out for separate theoretical concern. Legal rules are only one of a number of systems of rules, often overlapping and entwined, which shape people's aspirations and actions, and by which they are judged and resolve their troubles. In different cultures and at different times, law performs different functions and is entwined in different ways with other forms of social control and methods of dispute settlement. What may be regulated by law at one time or in one setting may very well be controlled by informal peer group pressure, self-help, or other authoritative institutions in another. ${ }^{9}$ Law, unlike kinship, language, or power, does not seem to be a fundamental phenomenon. Unlike these other phenomena law is not ubiquitous, and its nature varies; hence it does not capture a constant, identifiable activity, process, or set of relationships around which basic social theory is likely to be formed.

My argument here is in contrast to Selznick (1969), who takes the position that law is a fundamental social process, and who explicitly seeks a theory of the distinctively legal. Interested as he is, in private institutions and justice, Selznick (1969:

4) argues that:

If we are to study justice in industry, or in any other specialized institution, we must first be clear that law is found in many settings; it is not uniquely associated with the state. We need a concept of law that is sufficiently general to embrace legal experience within "private" associations, but not so general as to make law lose its distinctive character or become equivalent to social control.

When an institution possesses authority and issues rules, it is, according to this formulation, a legal order. Selznick writes (1969:5,7): "A legal order is known by the existence of authoritative rules," and "We should see law as endemic in all institutions that rely for social control on formal authority and rule-making." The argument that law is generic appears convincing, but only because "the view of law sketched here assimi-

9. See, for example, the discussion of the varying scope of law in Hoebel (1954). 
lates the theory of law to the theory of authority" (1969:7). The two concepts are joined into one; they incorporate each other.

But this may be forcing uniformity at the expense of great distortion. To equate the two concepts in the search for a sufficiently general phenomenon may point to the ubiquity of rule-governed behavior, and may lead to a useful understanding of the normative order, but it seems also to lose sight of important distinctive features of what are commonly considered legal rules. To equate the law of the state with the "law" of the internal operations of the corporation, the "law" of the monastery, and perhaps the rules of grammar, is I think to obscure important differences, differences that other readers of jurisprudence would not so readily abandon, and differences which are rooted in the traditional concerns of social scientists, who grant coercion a greater function in the legal order than does Selznick. To assimilate the two concepts may lead to the blurring over of the very distinction and question that is central to much sociolegal research: under what conditions does law supplant other forms of authority?

To suggest that coercion occupies a more distinctive element in the concept of law than Selznick appears to give it, is not however, to argue that law is nothing other than an arrangement of static commands to be followed upon fear of pain and suffering. As I argue below, such a narrow concept of law has already impoverished too much social science research on legal phenomena. But virtually to abandon coercion as a necessary element in the concept is, I think, to err in the opposite direction, and Selznick, although he attempts to, provides no convincing reason for doing so. He writes (1969:8):

To equate law and the state impoverishes sociological analysis, because the concept of law should be available for study of any setting in which human conduct is subject to explicit rulemaking; and when we deny the place of law in specialized institutions we withhold from the private setting the funded experience of the political community in matters of governance.

This appeal is not convincing. It fails because it confuses similarity with identity. That there are similarities among various types of authoritative systems of rules no one would deny. That insights can be shared and generalized no one would deny. Even to grant the "funded experience of the political community in matters of governance" to the "private setting" does not require that the two be totally equated. Similarities, even great similarities, need not be taken for identities, especially when the distinctions serve useful purposes. 
If law is in fact distinct in certain ways from other types of authoritative systems of rules, then it may not provide a useful focus for development of general social theory. What is distinctively legal in one culture may not be so in another. A dispute which in one society might be resolved by legal institutions may in another be pursued by self-help. If this is the case, dispute processing, not law, seems to be the more general social process around which social theory might be constructed. Law is only one possible component of the process, and clearly an exclusive focus on law would provide an incomplete understanding of dispute processing. In this perspective, there is no needindeed it would be incorrect-to attempt to factor out and treat separately that which is distinctively legal.

However, law obviously does deserve particularly careful attention from social scientists. Although its range and method vary across cultures and time, law permeates many walks of life, provides insights into many types of social processes, and in modern societies has assumed ever-increasing importance as a means of social control. These are reasons enough for considerable attention. My argument here is intended to cast doubt only on the wisdom of searching for a general theory of the distinctively legal. ${ }^{10}$

\section{Deficiencies of the Received Concept of Law}

Most contemporary research on law and society suffers from its unwillingness to even consider a definition of the concept of law and hence the boundaries of investigation. This reluctance is perhaps the most widely shared feature of social scientists interested in law. ${ }^{11}$ While it is dangerous to generalize about such an open-ended body of literature, my point is supported, I think, by the paucity of conceptual analysis of the central term-law-in most of the articles reprinted in six widely circulated law and society readers. ${ }^{12}$ With but a few excep-

10. In addition to Selznick, also see Auerbach (1966) and Skolnick (1966b).

11. There are at least two partial exceptions to this assertion. Both Hoebel (1954) and Barkun (1966) have prefaced their important works with such an attempt at conceptual clarification. They are, however, in my opinion both failures. In each irstance the works of Kelsen, Hart, Fuller, and other important legal theorists have either been ignored completely or dismissed without any serious examination. In contrast, see Gibbs' (1968) insightful but unfortunately neglected article in which he carefully examines various definitions of law and shows their importance in empirical research and in forming generalizations.

12. They are: Simon (1968), Friedman and Macaulay (1969), Schwartz and Skolnick (1970), Grossman and Grossman (1971), Black and Mileski (1973), and Akers and Hawkins (1975). 
tions the authors of these articles accept uncritically and without comment a view of law as direct command supported in varying degrees by the threat of sanctions. Indeed, most of the pieces reprinted in these volumes deal with the criminal law, and even when they do not, the criminal law-command paradigm is often maintained in discussions of regulatory activities.

There are a number of weaknesses in this conception of law as command. Two in particular seem to have adversely affected social science research: 1 ) the conception of law as command is overly static, and 2) it is so preoccupied with a criminal law model that it ignores other forms of laws.

By overly static I mean that law tends to be characterized as a set of do's and don't's, as direct commands requiring specifiable, particular responses. Such a view ignores laws that do not define and mandate specific behavior. Kelsen and many others have argued that systems of laws are composed of a mixture of both static and dynamic norms and have criticized Austin's conception of law for being exclusively preoccupied with only some types of static norms. This seems to be a needed corrective to most current social science conceptions of law as well. Following Kelsen's terminology, static norms are provisions which require specific behavior or define specific actions. While broader than commands, they would include the stark do's and don't's issued by Austin's sovereign. On the other hand, dynamic norms are laws about laws; they define offices and grant authority to designated persons or offices. They may specify the ways in which additional norms are to be enacted, outline the boundaries of official discretion, and prescribe procedures for the exercise of power. They define, for instance, who is a public official. Further, actions by public officials derive from such laws and many important public policies may be traced to them. Thus, for example, specific, non-generalized decisions to send troops to Little Rock, or alter the prime interest rate, or redraw school district boundaries-all of which are lawful orders-all stem from open-ended dynamic norms, rather than from static laws mandating specific behavior. Most public policy-making is of this sort-filling out specifics or acting within a broadly drawn plan-as is obvious when the great variety of government administrative behavior is considered. Thus the laws which define and give legitimacy to official public positions and grant some degree of open-ended discretion are important aspects of legal behavior. They seem to me to be of particular concern precisely because they grant authority to engage in actions of great importance but also of extremely low visibility. 
The second weakness involves the limited perspectives of the command model of law. This model, most appropriate for the substantive criminal law, ignores a variety of other important forms of law, such as laws which simply define, laws which confer rights, and laws which provide selective incentives rather than negative sanctions. Although these are all important means of shaping public policies, none of them can easily be characterized as a command and it is probably for this reason that they are generally ignored in most discussions of law and social control.

Laws of definition simply define, they do not command. Nor are sanctions necessarily directly attached to them. For instance, in order to obtain a valid driver's license a person must be over eighteen, have good eyesight, and pass a driving test. Legal rules spell out these conditions. If one wants a license they must be followed; if they are not, no valid license is forthcoming. If a couple wants to be married, certain provisions must be met; if they are not, there is no valid marriage. If businessmen want a contract, they must follow certain procedures. If one wants an entitlement to property, certain conditions must be met.

To say that it is not particularly meaningful to speak of commands or compliance or noncompliance to these norms does not mean that they have no impact or significant effect on society or are not viewed instrumentally by public officials as means by which to pursue desired social change or control. Their impact is, however, likely to be in combination with other laws and actions and their effects indirect, in contrast to the command type of laws. The possession of a valid driver's license, marriage certificate, school diploma or piece of land are necessary for a host of subsequent opportunities, both public and private, and the control of recruitment and access to such opportunities is in part accomplished by variously defining eligibility requirements and opportunity costs. This manipulation can in turn be used as a conscious instrument of social control and change.

Laws may also be status conferring rules. Such laws selectively extend or withhold officially recognized status to designated classes of people. Perhaps most obviously they identify and create public officials themselves. These status-conferring laws are important in allocating public benefits and deprivations. Perhaps even more important is their effect on benefits flowing from private sources. Public certification of educational 
achievement, property ownership or tax payment are not only important with respect to voting, holding public office or receiving government benefits, but also with respect to opportunities they facilitate (or impede) within the private sphere. Such status-conferring norms, while appearing on the surface to be neutral laws, can have a variety of decidely non-neutral consequences. This fact has often been recognized and exploited by social planners.

Similar to status-conferring norms are laws which define individual rights as against the government. Their impact too cannot properly be understood in terms of the command model, although they may even take the form of commands. This is because one of their major functions may be to facilitate purely private activity. For instance, Arnold Rose (1954) compared voluntary associations in the United States and France. Noting their great variety and proliferation in the United States, in sharp contrast to their scarcity in France, Rose traced these differences to the variations in the laws of the two countries. He argues that American law (such as the First Amendment) performs an important facilitative function and tends to encourage and foster the growth of private voluntary organizations, while French law is restrictive and has a dampening effect. These laws, he concludes, have had profound consequences for mass political participation and the development of democratic institutions in the two countries. Most important for our present purpose, Rose asserts that these consequences are in part planned, conscious policies, not unanticipated by-products of other actions.

A more contemporary and perhaps more obvious example of the facilitative function of rights-laws is seen in the recent Supreme Court ruling on abortion. The full impact of this decision cannot meaningfully be captured by conventional impact analysis, which would characterize the ruling in terms of a command and would focus on how doctors, hospitals and legislatures responded to the decision. Rather, its most significant impact may be its symbolic legitimization of biological manipulation or its fostering a new definition of life and death. Other more immediate effects might be the altered number of women in the labor market, changes in size and composition of families, reductions in population growth, and changes in the class and ethnic composition of society. By varying the availability of abortion and contraception, Eastern European countries so I am told, have for a number of years attempted to affect the size of the labor force and the rate of population growth. 
Provisions which selectively and strategically distribute incentives are another kind of law which is often ignored in the command view of law. Clearly the use of incentives is an important feature of legal policymaking, especially in a market economy and contract-oriented society where so much of government action takes the form of exerting marginal influence and control over activities nominally within the "private" sector. Perhaps the most obvious types of incentives are taxes, subsidies, and outright grants. Surprisingly, sociologists and political scientists have almost completely ignored these forms of law as instruments of calculated social control, leaving them to be considered by lawyers and economists. Although acknowledging that the power to tax is the power to destroy, political scientists have put little effort into the examination of the ways in which tax rates and coverage have been used to stimulate desired social ends or impede undesired activities (e.g. oil depletion allowances, capital gains tax rates, exemptions for certain organizations). ${ }^{13}$ Sanctioning is a double-edged sword; not only can law shape conduct by the threat or application of negative sanctions, it can also pursue goals by selectively awarding benefits. Perhaps the most dramatic instance of such incentives is the Homestead Act of 1862, which provided free land and significantly affected the growth of the American West. Other examples of instrumental use of subsidies include tax breaks for home-owners, condemnation rights, cheap or free land to railroads, and lower than cost services to stimulate certain "private" activities and retard others.

Perhaps some societies have systems of legal rules comprised primarily of stark do's and don't's, but it is likely that most societies rely extensively on other forms of laws as well. These other forms provide especially subtle means of legal control, in part because they effectively render the influence of the state invisible, concealing the political character of social conflict and resource allocation. They facilitate and guide the development of private law-making (e.g. contracts), provide a means of effecting marginal adjustments in purely private processes, and generally provide for a far greater variety of alternatives than those available in a system of static rules in the form of stark commands.

Each of these several types of laws-definitions, status and right conferring, and selective incentives-are distinguishable from command laws in a number of ways. Usually their form is

13. For analyses of the various functions and consequences of tax laws see Bittker et al. (1968) and Surrey (1973). 
different. This no doubt has contributed to their being more or less ignored in social scientists' discussions of law and social control. Their impact too tends to follow a different path. Changes brought about by such laws are not likely to be formally stated, clearly identified or even widely acknowledged. Neither are they likely to be immediately obvious to the outside observer and at times even to all their sponsors. Further, in contrast to the bluntness of most command-type laws, these facilitative types of law are likely to pursue their ends by altering the rates of an activity rather than flatly prohibiting or requiring a prescribed pattern of behavior. In relatively stable complex societies and particularly in market-oriented societies, the various kinds of facilitative laws taken together are probably more important as instruments of change and control than are the blunt command-type laws.

\section{A REFORMULATION OF THE CENTRAL CONCEPT}

A careful analysis of the nature and scope of law is required before empirical generalizations about its functioning can assume theoretical intelligibility. I have argued that the dominant Austinian conception of law pervading most of the social sciences is too narrow, and have identified several important forms of law which it tends to omit. This narrowness of concept, I have argued, has its parallel in the narrowness of empirical investigation and generalization. These observations in turn have prompted a brief examination of the functioning of other forms of law.

Although most sociologists and political scientists have steered away from such conceptual analysis, such concerns are central to the province of legal philosophy. Indeed analytic jurisprudence since Austin has been preoccupied with identifying the nature and scope of law and locating the role of coercive sanctions in the law. Both Kelsen (1961) and Hart (1961) have criticized the Austinian command model for its failure to include much that is commonly understood to be law.

To challenge the command model and its conception of the function of sanctions, one need not propose a definition of law altogether devoid of a coercive element. ${ }^{14}$ Indeed even the harshest critics of the Austinian school have not abolished sanctions as a necessary element in the concept of law, but have sought to give them a more subtle and indirect function. For

14. Some social scientists have, however, mistakenly engaged in such an attempt. See Barkun (1966). 
instance, I argued earlier that some laws are purely definitional, and have no sanctions attached to them. This does not mean, however, that coercion is not intimately entwined with such laws as they connect with other laws and practices. Obviously sanctions are associated with marriage laws, as any unmarried taxpayer can attest. I am not proposing here to make a substantive contribution to the continuing philosophical debate. Nor do I want to undertake an extended analysis of all the problems raised by such an inquiry. Rather I want to draw on the distilled wisdom of these discussions in order to enlarge the conceptual basis for orienting empirical investigation and developing social theory. My point is merely to emphasize that social scientists have not drawn on a concept of law that adequately addresses forms of law other than commands, a conceptual failure that has led to improperly drawn boundaries of investigation. More importantly, empirical investigations premised upon this initial failure have led to generalizations about law and society that are of questionable usefulness.

Having done little more than point to the need for development of a richer concept of law, I will here only suggest that a reformulated understanding must comprehend at least two features of the law: the variety of its functions and the variety of its forms.

\section{A. The Functions of Law}

Are the purposes of laws stated directly, generally acknowledged by their framers, and obvious to the target population? While typically there may be a public consensus as to the literal intent and purpose of some criminal laws (even if the purposes are not always agreed with), there may be other less obvious functions of these laws as well. For other laws there may be little or no consensus on purpose at all. Not only do the manifest functions of laws require identification, so too do the variety of latent and indirect functions, for it is these "byproducts" that may in fact have given rise to the law's passage. For instance, while tax laws are universally regarded as means of raising revenue, the variety of other purposes pursued through such laws may be less obvious to those affected by them, although clearly intended by the sponsors of the laws. Their importance as mechanisms of social control-apart from revenue raising and spending - must clearly be acknowledged.

Tort law provides another interesting example of the indirect social control functions of law. Tort law has evolved into a 
multi-faceted instrument capable of pursuing simultaneously a variety of important although not immediately obvious social control goals. If early theorists of tort law did not discuss them, such social control functions of tort law are not now viewed as unanticipated consequences of the purely private law of torts, but rather are considered a vital component of the conscious (although not publicly visible) development of the law itself. Such diverse governmental policies as crime control and workman's compensation have all had their roots in the "private law" field of torts; and such questions as general deterrence, income distribution, and industrial growth are now included in theoretical discussions of the "private" law of torts. ${ }^{15}$

These features of tax and tort law are not, however, generally thought of by social scientists in terms of social control. Taxes by and large are viewed as devices to raise revenue, and tort law, if thought of at all, is viewed as a means by which private individuals can recover damages done them by others. Nevertheless, as my brief discussion suggests, important and wide-ranging public purposes are consciously pursued as seemingly by-products of the publicly announced purposes of these laws. But what may be regarded as a latent and inconsequential function for some may be manifest to others, and in modern societies complex laws are likely to be adopted and supported precisely because they are capable of pursuing a variety of diverse purposes simultaneously. Because they are preoccupied with laws as commands, socio-legal scholars frequently do not cast their nets wide enough to identify these other kinds of laws or the multiplicity of functions of laws, and as a consequence they often understate and ignore important efforts at social control, efforts which are all the more important because they go unrecognized by a broader public, are frequently of low visibility, and are effectively depoliticized, matters for "specialists" and not for widespread "public debate."

Social scientists naturally tend to focus on celebrated commands and direct orders of the highly visible policy-makers who are wrestling with the glamorous issues of the day. However, much governmental policymaking is institutionalized in positions of low visibility with partial and fragmented responsibilities (cf. Shapiro [1970]). This observation, which has repeatedly been made with respect to the importance of bureaucracies in modern societies, is particularly applicable to courts in common

15. The public policy perspective and the acknowledgment of multiple functions of tort law is by now more or less the orthodox position. See Calabresi (1970) and Posner (1973). 
law countries, where important policies are not only developed in a fragmented incremental way but are also effectively "depoliticized."

\section{B. Forms of Law}

Efforts at social control through law can range from explicit commands to the manipulation of field controls of entire populations. ${ }^{10}$ The command approach envisions an ideal pattern of behavior for every individual within a clearly designated class. Field controls, on the other hand, are designed to affect the behavior of only a (usually small) portion within a target group by altering its field or environment so that some individuals' choices and behavior will be altered. Such manipulation of the environment is analogous to raising and lowering prices to affect demand, consumption, and substitution. This form of legal control is aimed at conditions and aggregates rather than specific individuals.

In contrast to the bluntness and directness of laws in the form of commands, laws designed to manipulate fields are likely to approach their goals indirectly. They are not intended to command each individual to follow a precisely prescribed path, but rather aim at an aggregate or systemic response. They are designed to control the rate of an activity by altering the costs of engaging in it. Presumably increasing the cost of participation will decrease the demand for the activity and redirect interests elsewhere. For example, rather than rationing gasoline or flatly prohibiting automobiles with large engines, the same goalreducing fuel consumption-might be pursued by placing progressive taxes on automobiles according to their fuel consumption. Or in order to reduce the number of traffic fatalities due to defective automobiles, owners might be commanded to periodically have their automobiles inspected. Or the same goal might be pursued indirectly. Mandatory insurance laws have the effect of discouraging the use of old (and increasingly unsafe in the aggregate) automobiles. Drivers, unwilling to invest the high costs of insurance in low value automobiles, as a consequence may not drive them. Likewise innovation and economic growth can be stimulated by the selective use of tax credits. The possible advantages of this indirect approach are obvious. It is largely "self-enforcing," and provides greater flexibility than would all-or-nothing commands. ${ }^{17}$

16. This distinction is adapted from the discussion by Dahl and Lindblom (1953: 93-128).

17. For an interesting analysis contrasting the failures of subsidized 
Obviously commands and field controls of aggregates are two extremes along an ill-defined continuum and are subject to a variety of ambiguities, especially since the same law (or set of laws) may frequently contain both types of controls. ${ }^{18}$ Nevertheless, the distinction is useful to characterize and emphasize the range of forms that legal control may take. Command-like laws are likely to be more direct and more visible to the affected individuals, than are field controls. The latter are, I suspect, more characteristic of efforts at planned social control and change in complex societies.

Reflection on this variety of forms of legal control suggests that the conditions for the efficacy of law traditionally offered by public law scholars and sociologists may be misleading, too narrow, or wrong. For instance, one scholar (Rogers, 1971: 646) has

... hypothesized that congruence between policy outputs and policy outcomes will be greatest when four measurable conditions prevail: 1) When the regulated agree both that a legal standard has been established by a legitimate source and that the standard requires compliance ... 2) When the law clearly and carefully defines both who is responsible for seeing that a law is obeyed and the type and amount of compliance required ....3) When the regulated perceive that certain and severe sanctions will result from noncompliance ... 4) When those who are to receive the benefits of the law are cohesive and take strong actions to achieve their rights.

These observations may be almost wholly irrelevant when applied to facilitative laws, the efficacy of which rests on their ability to shape consumer choices. In fact, something like the opposite may obtain. The more complex, multipurposed, and indirect the laws aimed at marginally affecting the rate of some activity, the less likely that the policy implications and the path between cause and effect may even be detected by the affected population. Law, then, can be a powerful tool of social control and change precisely because it can adjust for intensity of preference and can be exercised without always having recourse to direct clearly announced commands, clarity of purpose, or understanding by the affected population. ${ }^{10}$ Not only can law

housing programs with the successes of promoting homeownership by tax deductions for mortgage interest see Baer (1975).

18. Command-type controls resemble field controls insofar as total compliance of all individuals is rarely expected or obtained. At some point the costs of increased enforcement outweigh the costs of noncompliance so that some crime becomes socially efficient. The differences in the form of control, however, are still important.

19. Curiously critics of pluralist theories of American politics have failed to examine the functions of law in structuring inequalities. Their criticisms of law tend to sound much like those of their pluralist opponents; both focus on the degree of differential access to the resources of law or on a few "big decisions" rather than examine the 
powerfully influence behavior while those affected by a policy remain entirely unaware of it, but it may effectively depoliticize the policymaking process.

\section{TOWARD AN EXPANDED VIEW}

In the preceding sections I pointed to the need both to broaden the concept of law and to enlarge the understanding of its functions and forms, and called into question some received generalizations about the law and social control. ${ }^{20}$ In light of this two central questions emerge: What is the scope and nature of activity to be included within the study of law and social control? What is an appropriate theoretical perspective?

Much of the literature on impact and compliance to law, concerned as it often is with blunt commands, has tended to focus on the pronouncements of and responses to court decisions. This is clearly too narrow a focus. Courts as we know them do not exist in some societies, nor in most societies are they major sources or interpreters of law. Legislatures and administrative bodies probably far outweigh them in both volume and importance as sources of commands. Clearly, then, an exclusive focus on court decision-making and the consequences of these decisions is too narrow and ignores too much of what is commonly considered legal activity. ${ }^{21}$

What, then, would be the proper focus of an expanded study of law and social control?22 Black (1972b: 126) has

structural features of the legal system itself. For a brilliant corrective to this shortcoming see Pashukanis (1951).

20. One rather obvious conclusion is that the distinction between private and public law is of dubious value for analytic purposes and for drawing the boundaries of the field. In a recent article Shapiro (1972) has gone a long way toward abolishing this distinction for political scientists, but his argument seems to fall one small step short. His basic contention is that the categories are often not useful since many so-called private laws (e.g. torts) are easily shown to be infused with explicit considerations of public policy and hence are political. I am in total agreement but would urge the point even more strongly. All laws are by definition political; they allocate values, are authoritative, and hence are policy. Thus all law-making from whatever source is political policy-making. This is not to obliterate the important, if complex, distinction between rule-enforcement and rule-making. While there may be "neutral" norm application, there are no value neutral norms.

21. This focus on courts and judges may be the residual legacy of the legal realists' influence. Cf. Fuller's (1940:53) response to their position that the law is what the judges in fact do:

... why should we stop with judges and exclude commissioners? And for that matter, what of officials whose duties are even further removed from those of a judge, like a sheriff and the sanitary inspector? They too "behave" in ways that are important to the rest of us, and they too have their rules that they can talk about and their rules they act on.

22. For a deliberate choice of dispute processing as a focus, see Abel (1974). After wrestling with how law and legal disputes might be 
suggested that a major focus should be on the process of legal mobilization since:

The day-to-day entry of cases into any legal system cannot be taken for granted. Cases of alleged illegality and disputes do not move automatically to legal agencies for disposition or settlement. Without mobilization of the law, a legal control system lies out of touch with the human problems it is designed to oversee. Mobilization is the link between the law and the people served or controlled by the law.

This focus seems desirable because it moves beyond a narrow concern with courts to include all "legal agencies." But it also raises the question of what precisely is a legal agency? Obviously courts are and administrative agencies are, but what about arbitration panels? Any institution that "settles" disputes by means of applying "legal" rules? Attorneys in their offices making appeals to a hypothetical neutral tribunal as they negotiate with each other for their clients? Certainly mobilization is a "link between the law and the people served or controlled," but is is difficult to say much about this link until its nature and scope are clearly specified. Thus, for instance, it would be of questionable value to consider the mobilization of commercial law complaints in the courts without simultaneously understanding the mobilization of commercial law complaints in arbitration, an institution that the above quote may or may not envision as a "legal agency." One cannot say how a single element contributes to the whole until that whole is first identified. In this instance a failure to identify the nature of the legal agencies and the scope and boundaries of the mobilization process makes it difficult to say much about the frequency and consequences of mobilization, or to compare the process of mobilization in different areas of the law.

The focus on mobilization is bothersome for another and more important reason. Even when acknowledging that mobilization "mediates between the prescriptions of law and the disposition of cases" (Black, 1972b: 127) the focus is nevertheless incomplete and misses perhaps the most important way in which law intrudes into people's lives. The genius and the power and the importance of legal authority is precisely because it is selfapplying and self-mobilizing. By this I do not mean only that disputes can be brought into court by private citizens as well as public officials. I mean that the locus of the primary social

isolated for analysis, Abel, a lawyer-anthropologist, concludes that the task is not particularly fruitful. He then proceeds to develop a theory of not just legal dispute processing, but all dispute processing, which he argues is the more general phenomena, the more theoretically justifiable, and more applicable to cultures whose notions of disputes, rules, and law differ markedly from those in the West. 
control function of law is not found in the specific orders emanating from the occasional "trouble cases" which have for one reason or another necessitated mobilization of formal legal machinery. Indeed these cases, an undetermined and highly unrepresentative small set of situations, probably represent an extreme "last resort" in the process of control. Rather the law is most often set in motion by people who apply it to themselves and to each other without benefit of explicit mobilization of legal institutions. The basic aspect of law and social control is found in the unheralded response and anticipations to abstract sets of rules which intrude in the lives of people and get them to do things they would otherwise not do. The mobilized cases, in a sense, may represent little more than the occasional failure or rupture in an otherwise largely invisible or at least self-applying system of control.

The problem of how to treat rules has always puzzled social scientists. Rules are abstractions, impossible to "observe" and difficult to assign cause to. Thus it is understandable that in an effort to come to grips with the control functions of law so many would want to latch onto the easily observed "behavior" of officials, receiving complaints, making legal rules, and applying them. But to focus on the courts or the mobilization of cases is to miss the most essential and most powerful features of social control through law. In a host of both blunt and subtle ways law creates a set of categories through which people must filter their thinking and organize their lives. It is a complex pricing system which not only puts a value on the wants people may be inclined to pursue, but also affects them indirectly in that people must also adjust their wants to the behavior of others whose preferences are in turn shaped by the law. Thus law may be used to control people in a variety of ways that cannot be understood from the mobilization perspective.

An emphasis on judicial activity and mobilization overlooks the power of law to "resolve" issues through anticipatory reaction, and informal application.":: For instance, disputes in "private law" fields are usually settled by the parties themselves as they invoke "the law" to support their positions. Petty crimes are often "settled" by means of restitution after the victim threatens to call the police, and individuals often apply the law to themselves and adjust their behavior accordingly in order to avoid these possibilities altogether. In each case a law, a legal forum or an agency may be invoked but not directly activated.

23. For an examination of the problem of anticipated reactions in relation to the study of Supreme Court decisions, see Feeley (1972). 
To test the shortcomings of the mobilization focus, one can, without too much suspension of disbelief, conceive of a legal system or at least areas of law in which there are no conflicts and thus no disputes to settle and no cases to mobilize. It would, however, be erroneous to conclude from this absence of activity that the law was having no effect at all. Quite the contrary, it might be argued that the law was operating with perfect efficiency since would-be disputants always anticipated the likely consequences of their proposed actions and declined to pursue them. It is one of the tasks of the empirical study of law to sort out the various explanations for such behavior in this and less extreme situations. Such a concern turns the primary focus away from the courts, police, and other "legal actors" and away from mobilization or "trouble cases" to focus on the public at large, including those who are not drawn into the formal mechanics of dispute processing or mobilization. ${ }^{24}$

An increasing number of socio-legal scholars are beginning to react against the narrow focus imposed by the concern with mobilization and "trouble cases" in formal governmental forums. Within recent years there has been a growing recognition among criminologists that the central questions of law and social control may not deal with characteristics of criminals, the activities of police, or how cases get or do not get to court, but rather with the general preventive effects of law. While many people break the law, some of them are discovered, and a few of them are apprehended, why do others comply with the law? How many of them decline to engage in an activity because it is prohibited by law? Which is more important, the magnitude of the criminal sanction or the likelihood of apprehension? How does criminal law function as a moralizing and threatening instrument? These are but a few of the questions raised by this perspective.

This perspective was given impetus by Andenaes' influential article (1966), and since then has received considerable attention from other social scientists (Gibbs, 1975, Zimring and Hawkins, 1973, Tittle and Logan, 1973, Ehrlich, 1972). Andenaes speaks of general preventive effects of punishment (the "effects of punishment upon members of society in general") and specific prevention (the effect "on the many being punished"). He argues convincingly (1966: 950) that the major focus for students of the criminal law should be on general prevention, despite the fact that "... general prevention is

24. Gerstein's (1970) discussion of "The Practice of Fidelity to Law" also seems to reach this conclusion. 
more concerned with the psychology of those obedient to the law than with the psychology of criminals." In essence, he concludes, the primary focus of attention should be on those people whom the law deters and who, therefore, are never brought within the grasp of the formal legal machinery or officials. The importance and implications of this point are elaborated with great clarity in Jack Gibbs' (1975) thoughtful book which systematically catalogues a number of properties of punishments of crimes which are likely to be relevant in developing a theory of deterrence. ${ }^{25}$

The focus on the general preventive effects of law is quite appropriate for criminal law, and the same set of questions can easily be generalized to other forms of "command" as well. However, this focus suffers from all the limitations of the command conception of law in general, and requires modification before it can assume a form generalizable for all laws and serve as the basis for focusing inquiry on law and social control. Rather than referring to general and specific prevention or deterrence, it is possible to speak of general and specific effects. General effects refer to the larger public consequences of a particular law or system of laws, including those indirect effects not necessarily perceived by the persons whose activity is being regulated. On the other hand, specific effects refer to the processes and consequences of laws which require conscious participation by individuals in mobilizing the machinery of law to process a dispute or pursue a claim.

For example, the general effect of automobile accident law may involve such things as the conditions insurance companies place on their policy holders, which in turn have consequences for the frequency, seriousness, and costs of accidents, while the specific effects have to do with the immediate behavior of those individuals involved in an accident or otherwise brought into the

25. The several properties of punishments which Gibbs (1975:144) identifies as likely to have a bearing on general deterrence are: 1) objective certainty, 2) perceived certainty, 3 ) perceived severity of prescribed punishments, 4) perceived severity of actual punishments, 5) presumptive severity of actual punishments, 6) objective celerity, 7) perceived celerity, 8) presumptive severity of prescribed punishments, and 9) knowledge of prescribed punishments. He observes: Needless to say, the prospect of treating all nine properties in a deterrence theory is foreboding; hence it would be desirable to dismiss some of the properties as irrelevant. But such selectivity cannot be justified at this stage. . . All of the foregoing should make it clear that the methodology of deterrence research cannot be simple unless one is willing to tolerate oversimplified, incomplete, and crude investigations.

Many of these same properties and this observation have a direct application for those interested in pursuing the more general inquiry into law and social control as well. 
mobilized machinery of the law. To take another example, increasing the liability of a manufacturer for the safety of its products may produce a rash of law suits and facilitate the claims of injured consumers, but the general effects may be to alter the price of the goods, to stimulate the use of substitutes, to improve quality control in the industry, and perhaps even to cause the collapse of the industry. Changes in laws affect in a variety of anticipated and unanticipated ways the costs of engaging in an activity. Specific effects of laws concern the immediate response and reaction to the law; general effects involve an examination of how individuals and organizations adjust to and cope with increased or decreased costs of pursuing their own interests (whether purely private or public).

In this view law can be conceived of as an elaborate and subtle pricing mechanism which cannot only flatly prohibit or expressly require, but can also supplement and shape natural systems of exchange and interaction by slightly adjusting the costs of an activity. Thus it must be understood as only one of a number of interrelated factors in complicated systems of interaction. ${ }^{20}$ Varying the nature and content of the law, whether it is the substantive or procedural criminal law, rules of standing, or any type of public or private law, can affect ongoing systems in a variety of ways by altering supply, demand, opportunity, alternatives, transaction costs, etc. of those participating in the system. All this can ultimately be translated into general effects on the rate and duration of an activity. ${ }^{27}$ Its main control effects are not limited to the occasional instance when someone challenges the propriety and ambiguity of the pricing system, but rather the great bulk of the instances when people accept it and alter their behavior accordingly.

While some activities are likely to be controlled or affected by direct commands, control through devices manipulating environments and producing indirect effects is probably a more typical feature of control in complex societies. The law is a much more subtle and finely tuned instrument for expressing and controlling the distribution of values than those preoccupied with the blunt command model of law usually envision. It includes a great variety of techniques and forms, can operate in an indirect and almost imperceptible way, and can unobtrusively enter into all walks of life. In common law countries all this is

26. Cf. my attempt (Feeley, 1970:407) at a general explanation for the adoption of criminal laws in all societies.

27. The single best introduction to this perspective is Posner (1974). For some critical appraisals of this book, see Leff (1974), and Buchanan (1974). 
reinforced by the decentralized, incremental and depoliticized nature of the judicial policy-making process. This may be further reinforced by the growth of large private organizationsinsurance companies, banks, corporations, unions, universities, etc.-that engage in extensive planning in anticipation of possible legal effects and as a means of avoiding trouble cases. Thus procedures for avoiding legal trouble are built into their own "private" control systems.

The perspective outlined here may appear foreign to many social scientists, but is familiar to economists. While sociologists and political scientists, for instance, are prone to look for commands or command-like statements of regulation when considering forms of legal control, economists are more likely to see social life in terms of on-going systems of private exchange, and to approach the analysis of legal control by searching for factors that indirectly affect these systems. The differences, however, go deeper and also involve the ways problems are characterized and theories constructed.

Some of these differences may be illustrated by examining how the two approaches might characterize a research problem. The more empirically oriented social scientist might focus on the law as an independent variable and then trace its consequences-the dependent variables-with either a comparative or before/after research design. This is typical of many compliance and impact studies. On the other hand, the economist is more likely to first identify the elements and dynamics of a process of social choice, generate a theory about the calculus of choice and then examine the system as a whole, with perhaps a special emphasis on the functions of law. The single independent variable (the law) and the causal language of the former are in sharp contrast to the latter, which would speak of a process of interaction, in which "the law" would be only one of a number of factors. ${ }^{28}$

28. Compare, for example, a sociologist's approach with an economist's approach to the analysis of criminal sanctions. Using a standard research design, Schwartz and Orleans (1967) in a study entitled "On Legal Sanctions," identify the legal threat of criminal sanctions as one independent variable, try to control for all other possible sources of change, and then compare sanctions with other treatments to ascertain resulting behavioral changes (in this case increased tax payment). They then offer some concluding generalizations about the efficacy of legal sanctions compared to other treatments. On the other hand, Ehrlich (1972), an economist, constructs a model of individual choice under various conditions, including the possibility of the application of criminal sanctions. In constructing a general model of individual choice, he identifies a variety of elements entering into a decision, only one of which is the likelihood of sanctions being applied. He proceeds to examine how individuals make deci- 
If theoretically inclined at all, the "empirical" approach would lead to construction of a "theory of impact" or effectiveness. On the other hand, the economic approach would generate a theory of decisionmaking under a specified set of conditions. If it were a decision which was directly or indirectly affected by the law (e.g. a command flatly prohibiting an action or a provision indirectly affecting the cost of an activity), then one of the elements in the calculus of choice would be "the law." This conception views law as a subtle pricing mechanism which seeks to stimulate or retard processes-whether public or private-by varying the costs of participation in them. This approach, however, does not lead to a distinctive focus on law itself, since law is simply one of a number of elements in the decision. As a part, it can only be understood in the light of the whole.

The broader conception of the functions of law ought also be congenial to Marxists, whose conceptions of the state are broad enough to include both public and private law of AngloAmerican political and legal theory. Marx, for instance, could examine the origins of the family and private property in his discussion of the state. Indeed the modern state, in his conception, is little more than the superstructure of laws and institutions assuring the privilege of the dominant classes by guaranteeing their existence and facilitating their "private" activities and relationships. "The modern state," Marx cogently asserted in the Manifesto, "is merely a committee which manages the common business of the bourgeoisie." Clearly such a view not only obliterates the importance of the distinction between public law and private law but also the distinction between command-like and facilitative laws.

This paper is not intended to develop a comprehensive theory of law or to urge agreement on the domain of the field of law or on a single preferred theoretical approach. The major thrust of my comments has been to direct the attention and interests of those engaged in legal studies to a broader conception of law and to a greater variety of functions and forms of law. More particularly this paper appeals to social scientists to recognize that all law-making and law-application is the exercise of political power and to focus attention on a greater variety of laws and problems than heretofore. Ironically, however, my

sions when one of the elements of consideration is the possibility of sanctions being applied, and then tests his deduced propositions against data on crime and arrest rates. 
position, if followed, seems to lead to the abolition of a rationale for a distinctive discipline of legal studies or a separate theory of law and society.

\section{REFERENCES}

ABEL, Richard (1973) "Law Books and Books About Law," 26 Stanford Law Review 175.

Society" (1974) "A Comparative Theory of Dispute Institutions in Society," 8 Law \& Society Review 217.

AKERS, Ronald and Richard HAWKINS (1975) Law and Control in Society. Englewood Cliffs: Prentice-Hall.

ANDENAES, Johannes (1966) "General Preventive Effects of Punishment," 114 University of Pennsylvania Law Review 949.

AUERBACH, Carl A. (1966) "Legal Tasks for the Sociologist," 1 Law \& Society Review 91 .

AUSTIN, John (1832) [1955 Reprint] The Province of Jurisprudence Determined. London: Weidfield and Nicholson.

BAER, William C. (1975) "On the Making of Perfect and Beautiful Social Programs," 39 The Public Interest 80.

BARKUN, Michael (1966) Law Without Sanctions. New Haven: Yale University Press.

BECKER, Theodore and Malcolm FEELEY (1972) (eds.) The Impact of Supreme Court Decisions (2d Edition). New York: Oxford University Press.

BITTKER, Borris I., Charles O. GALVIN, R.A. MUSGRAVE and Joseph A. PECHMAN (1968) A Comprehensive Income Tax Base? A Debate. Branford: Federal Tax Press [Reprinted in part from 80 and 81 Harvard Law Review (1967-1968) ].

BLACK, Donald (1972a) "The Boundaries of Legal Sociology," 81 Yale Law Journal 1086.

Studies 125.

(1972b) "The Mobilization of Law," 2 Journal of Legal Studies 125. zation of Law. New York: Academic Press.

BLUMBERG, Abraham (1970) Criminal Justice. Chicago: Quadrangle Books.

BUCHANAN, James (1974) "Good Economics Bad Law," 60 Virginia Law Review 451.

CALABRESI, Guido (1970) The Costs of Accidents. New Haven: Yale University Press.

CRAIN, Robert with the assistance of Morton INGER, Gerald A. MCWORTER and James J. VANECKO (1969) The Politics of School Desegregation. New York: Doubleday.

DAHL, Robert and Charles E. LINDBLOM (1954) Politics, Economics, and Welfare. New York: Harper and Row.

DERSHOWITZ, Alan (1973) "Preventive Confinement: A Suggested Framework for Constitutional Analysis," 51 Texas Law Review 1277.

EDELMAN, Murray (1964) The Symbolic Uses of Politics. Urbana: University of Illinois Press.

EHRLICH, Isaac (1972) "The Deterrent Effect of Criminal Law Enforcement," 1 Journal of Legal Studies 259.

ETZIONI, Amitai (1960) "Two Approaches to Organizational Analysis: A Critique and A Suggestion," 5 Administrative Science Quarterly 257.

FEELEY, Malcolm (1970) "Coercion and Compliance," 4 Law \& Society Review 407.

Becker and M. (1972) "Power, Impact, and the Supreme Court," in T. (2d Edition). New York: Oxford University Press.

(1973) "Two Models of the Criminal Justice System: An Organizational Perspective," 7 Law \& Society Review 407. 
FRIEDMAN, Lawrence and Stewart MACAULAY (1969) (eds.) Law and the Behavioral Sciences. Indianapolis: Bobbs-Merrill.

FULLER, Lon (1940) The Law in Quest of Itself. Boston: Beacon Press.

GERSTEIN, Robert (1970) "The Practice of Fidelity to Law," 4 Law \& Society Review 259.

GIBBS, Jack (1968) "Definitions of Law and Empirical Questions," 2 Law \& Society Review 429.

- (1975) Crime, Punishment, and Deterrence. New York: Elsevier.

GROSSMAN, Joel and Mary GROSSMAN (1971) (eds.) Law and Change in Modern America. Pacific Palisades: Goodyear Publishing Company.

GUSFIELD, Joseph R. (1963) Symbolic Crusade. Urbana: University of Illinois Press.

HART, H.L.A. (1961) The Concept of Law. Oxford: Clarendon Press.

HOEBEL, E.A. (1954) The Law of Primitive Man. Cambridge: Harvard University Press.

KELSEN, Hans (1961) General Theory of Law and State. New York: Russell and Russell.

KRISLOV, Samuel, Keith O. BOYUM, Jerry N. CLARK, Roger C. SHAFFER, and Susan O. WHITE (1972) Compliance and the Law. Beverly Hills: Sage Publications [Originally published as 4(4) and 5 (1) Law \& Society Review (1970)].

LASSWELL, Harold (1950) Politics: Who Gets What, When, How. New York: P. Smith.

LEFF, Arthur (1974) "Economic Analysis of Law: Some Realism about Nominalism," 60 Virginia Law Review 451.

MITCHELL, John (1969) "Bail Reform and The Constitutionality of Pretrial Detention," 55 Virginia Law Review 1223.

MOHR, Lawrence (1973) "The Concept of Organizational Goal," 67 American Political Science Review 470.

PASHUKANIS, E.B. (1951) "The General Theory of Law and Marxism," in $\mathrm{H}$. Babb (trans.) Soviet Legal Philosophy. Cambridge: Harvard University Press.

POSNER, Richard (1974) Economic Analysis of Law. Boston: Little Brown and Company.

ROGERS, Harrell (1971) "Law as an Instrument of Public Policy," 14 American Journal of Political Science 638.

ROSE, Arnold (1954) "Voluntary Associations in France," in Arnold Rose (ed.) Theory and Method in the Social Sciences. Minneapolis: University of Minnesota Press 72.

SCHWARTZ, Richard and Sonya ORLEANS (1967) "On Legal Sanctions," 34 University of Chicago Law Review 275.

SCHWARTZ, Richard and Jerome SKOLNICK (1970) (eds.) Society and the Legal Order. New York: The Free Press.

SELZNICK, Philip (1961) "Sociology and Natural Law," 6 Natural Law Forum 84.

Russell Sage Foundation.

SHAPIRO, Martin (1970) "Decentralized Decision-Making in the Law of Torts," in S.S. Ulmer (ed.) Political Decision-Making. New York: Van Nostrand.

(1972) "From Public Law to Public Policy or the Public in 'Public Law," " 5 PS 410.

SIMON, Rita James (1968) The Sociology of Law. San Francisco: Chandler Publishing Company.

SKOLNICK, Jerome (1966a) Justice Without Trial. New York: John Wiley and Sons. (1966b) "Social Research on Legality: A Reply to Aeurbach," 1 Law \& Society Review 105.

SUCHMAN, Edward A. (1967) Evaluative Research. New York: Russell Sage Foundation.

SUDNOW, David (1965) "Normal Crimes: Sociological Features of the Penal Code in a Public Defender's Office," 12 Social Problems 272. 
SURREY, Stanley S. (1973) Pathways to Tax Reform. Cambridge: Harvard University Press.

TITTLE, Charles, and Charles LOGAN (1973) "Sanctions and Deviance: Evidence and Remaining Questions," 7 Law \& Society Review 371. WASBY, Stephen (1970) The Impact of the United States Supreme Court. Chicago: Dorsey.

YALE LAW JOURNAL (1967) "Project: Interrogations in New Haven: The Impact of Miranda," 76 Yale Law Journal 1519.

ZIMRING, Franklin and Gordon HAWKINS (1973) Deterrence: The Press.

Legal Threat in Crime Control. Chicago: University of Chicago 
HeinOnline -- 10 Law \& Soc'y Rev. 528 1975-1976 